\title{
Intersections
}

Canadian Journal of Music

Revue canadienne de musique

\section{Katherine R. Syer. 2014. Wagner's Visions: Poetry, Politics, and the Psyche in the Operas through Die Walküre. Rochester: University of Rochester Press, x, 256pp. ISBN 978-1-58046-482-6}

\section{Daniel Sheridan}

Volume 35, numéro 2, 2015

URI : https://id.erudit.org/iderudit/1043827ar

DOI : https://doi.org/10.7202/1043827ar

Aller au sommaire du numéro

Éditeur(s)

Canadian University Music Society / Société de musique des universités canadiennes

ISSN

1911-0146 (imprimé)

1918-512X (numérique)

Découvrir la revue

Citer ce compte rendu

Sheridan, D. (2015). Compte rendu de [Katherine R. Syer. 2014. Wagner's Visions: Poetry, Politics, and the Psyche in the Operas through Die Walküre. Rochester: University of Rochester Press, x, 256pp. ISBN 978-1-58046-482-6]. Intersections, 35(2), 145-149. https://doi.org/10.7202/1043827ar

Copyright @ Canadian University Music Society / Société de musique des universités canadiennes, 2018
Ce document est protégé par la loi sur le droit d'auteur. L'utilisation des services d'Érudit (y compris la reproduction) est assujettie à sa politique d'utilisation que vous pouvez consulter en ligne.

https://apropos.erudit.org/fr/usagers/politique-dutilisation/ 
Katherine R. Syer. 2014. Wagner's Visions: Poetry, Politics, and the Psyche in the Operas through Die Walküre. Rochester: University of Rochester Press, $\mathrm{x}$, 256pp. ISBN 978-1-58046-482-6.

Richard Wagner's birth in 1813 carried greater significance than simply the advent of one of the most significant figures in the history of music. That he was born that year ensconced Wagner within a network of historical and socio-political events that situated 1813 as a key symbol in the struggle to cultivate a distinct German identity in the nineteenth century. So argues Katherine Syer in the introductory chapter of Wagner's Visions: Poetry, Politics, and the Psyche in the Operas through Die Walküre, a highly original and insightful study that examines the artistic and cultural bases for the numerous instances of characters experiencing altered states of consciousness in Wagner's operas through to Die Walküre. Syer already has an extensive research history on issues of psychology and musical and dramatic transformation in Wagner's works. ${ }^{1}$ In this book, Syer takes those longstanding scholarly interests and applies them to the pervading nation-consciousness of nineteenth-century German culture. In emphasizing moments of altered consciousness in Wagnerian drama, Syer effectively thematizes altered states as vital to the experience and understanding of German identity in the nineteenth century.

Syer's introduction, "To Be Born in Leipzig in 1813," develops from the premise that the 1813 Wars of Liberation against Napoleon set down a legacy that was foundational in the drive for German unity and rippled through the culture for decades. Syer systematically introduces each of these various "ripples" that inform her readings of the Wagner operas. During these segments, she includes preliminary observations on how the assorted issues function within the context of the operas, which then get expanded upon in later chapters. This tactic is effective in laying groundwork so that the introductory material need not be repeated later in the book. Syer then introduces the most pivotal figure of the book, who cast a long shadow over nation-conscious Germans in the nineteenth century: Theodor Körner, the playwright/poet and soldier in the Lützow Free Corps who was killed in 1813 and subsequently became an enduring symbol as a martyr for German liberation and unity. She draws special attention to his poem "Lützows wilde Jagd" ("Lützow's Wild Hunt"). The book maintains that the prevalence of hunting imagery in Wagner's operas bears the imprint of Körner's Wild Hunt and by extension the weight of its history as an enduring patriotic symbol.

1 Katherine Rae Syer, "Altered States: Musical and Psychological Processes in Wagner," $\mathrm{PhD}$ diss. (University of Victoria, 1999); "Unseen Voices: Wagner's Musical-Dramatic Shaping of the Grail Scene of Act I," A Companion to Wagner's Parsifal, eds. William Kinderman and Katherine R. Syer (Rochester, NY: Camden House, 2005), 177-214. 
Wagner's propensity for depicting altered states of consciousness is situated within various discourses of "unconscious mentation," with the practice of animal magnetism/Mesmerism given especial attention ${ }^{2}$; here Syer might have been better off providing more detail on the magnetizing process's supposed curative properties. As it is, her brief explanation prompts more questions than answers. Nonetheless, she is able to show how nineteenth-century interest in the workings of the psyche manifested itself in opera and had implications on burgeoning German nationalism. Syer's overriding theme is that Wagner's episodes of "unconscious mentation" function as expressions of the collective (and subconscious) cultural memory of the legacy of 1813. This theme persistently lingers in the reader's mind as the book progresses, even when Syer does not directly address it, because the seed had been so cannily planted early on.

Chapter Two, "Fairytale Madness" devotes its attention to a neglected part of Wagner's output, his first opera Die Feen. ${ }^{3}$ Syer focuses on the hero Arindal's longing for his lost wife Ada in the first and third acts, her readings encompassing the influences of Carlo Gozzi's 1762 play La donna serpente (Wagner's original source), Gluck, and Weber's Der Freischütz and Euryanthe. Here, Syer emphasizes these scenes' lineage to Gozzi and the "mad scenes" of seventeenth-century Venetian opera. Her musical analysis convincingly illustrates how Wagner's tonal plan of the monologue illustrates the progression through different states of Arindal's psychology. Syer's analyses of the score here and throughout are consistently sensitive to harmonic and thematic detail; my reservation is that her remarks on orchestration are frequently confined to identifying instruments instead of exploring how instrumentation can contribute to the depiction of altered consciousness. This chapter also effectively shows how numerous dramatic, psychological, and cultural motifs in Die Feen recur in Wagner's subsequent works.

Mesmerism plays a crucial role in Chapter Three, "Senta the Somnambulist," which focuses on Senta's Ballad and Erik's subsequent dream narration. Animal magnetism is not invoked arbitrarily: as Syer observes, the stage direction in the 1844 vocal score notes that Senta falls into something resembling a "magnetic sleep" (p. 9o). ${ }^{4}$ This chapter contextualizes the scene within discourses that advocated for the potential of magnetic sleep to heighten awareness and open subjects to enhanced levels of consciousness. Syer's score analysis of these two pieces are overall effective in accounting for various forms of musical gesture, physical, emotional, and psychological, but I wonder if there was a productive road not taken: while she is quite thorough in examining the musical depiction of psychological transformation, is there not also the potential to explore music's capacity to alter consciousness in and of itself? Additionally,

2 Maria M. Tatar, Spellbound: Studies on Mesmerism and Literature (Princeton, NJ: Princeton University Press, 1978).

3 Die Feen's obscurity is almost certainly the reason Syer opts to include a lengthy plot summary early in the chapter.

4 Alan Crabtree, From Mesmer to Freud: Magnetic Sleep and Roots of Psychological Healing (New Haven, CT: Yale University Press, 1993). 
given the prevalence of Weber, Gluck, and others in her explorations of moments of altered consciousness, speculation on changed psychology of the audience could easily be folded into her running theme of the psyche as a space for patriotic sentiment to flourish. At the chapter's close, Syer directs her focus to a diptych of paintings by Georg Friedrich Kersting that depicts both Körner and a young woman in a forest setting. 5 Syer uses these images to thematize Senta as an allegorical Germania figure, ${ }^{6}$ an interpretation both inventive and convincing that is valuable in framing Senta and Der fliegende Holländer as more potent symbols of German nationhood than they were perhaps previously credited for.

The migration between disparate realms are central to Chapter Four, "Opposing Worlds." Most of the chapter is focused on the infusion of patriotic imagery into the world of the Wartburg in Tannhäuser, but space is also reserved for the redolence of the Iphigenia operas in Lohengrin. After briefly reprising some of the concerns of the previous chapter, namely the prominence of Körner and German oak trees as symbols of the Wars of Liberation, Syer progresses through Tannhäuser's journeys traversing the Venusberg, the Wartburg Valley, and Rome, with such devices as the shepherd's song and the Pilgrim's Chorus musically bridging the distance between spheres. Syer then considers the legacies of the castles of the Wartburg and Schreckenstein in Bohemia, the latter being depicted in the book's cover image, an 1837 painting by Adrian Ludwig Richter. ${ }^{7}$ As Syer shows, there are connections between the two castles, Richter, cultural memory of Körner, and the contemporaneous 1840 os hopes for German unification. The presence of tree imagery in Richter's work leads Syer to uncover a political subtext to the opera's finale: the miraculous sprouting of green leaves on the Pope's staff, heralding Tannhäuser's redemption, is infused with the patriotic longing for German liberation. ${ }^{8}$ In the final segment, Syer demonstrates the musical points of contact between Wagner's revisions of Iphigénie en Aulide and his evocations of the Grail realm in Lohengrin. Just as Iphigenia will travel to a "distant land" (p. 147), so too will Lohengrin traverse a great distance from Montsalvat to Brabant, just as Tannhäuser bridged separate worlds. Syer's ability to integrate numerous ideas and sources into a cohesive and intriguing argument is once again commendable, but the noticeable disparity in pages devoted to Tannhäuser compared to Lohengrin makes the chapter seem imbalanced.

5 These paintings are respectively Auf Vorposten (On outpost duty) and Die Kranzwindern (The wreath-maker), both from 1815.

6 Bettina Brandt, "Germania in Armor: The Female Representation of an Endangered German Nation," Women and Death 2: Warlike Women in the German Literary and Cultural Imagination since 1500, eds. Sarah Colvin and Helen Watanabe-O'Kelly (Rochester, NY: Camden House, 2009), 86-126.

7 Die Überfahrt am Schreckenstein (The crossing at the Schreckenstein) (1837).

8 Apart from one musical example, Syer neglects to specify which of the two commonly available versions of Tannhäuser-the so-called "Dresden" version and the "Paris" version-she is working with. As there are major differences between the two scores in several scenes, it is necessary for Syer to be absolutely clear about which version she is working from to prevent any possibility of misleading the reader. Werner Breig accounts for all extant versions of the opera in "The Musical Works," Wagner Handbook, trans. John Deathridge, eds. Ulrich Müller and Peter Wapnewski (Cambridge, MA and London: Harvard University Press, 1992), 422-27. 
Political undercurrents are naturally abundant in the final chapter, "Hunding's Horns, Wotan's Storms, Sieglinde's Nightmare," dealing as it does with the first two stages of the Ring. The tetralogy is rich in psychological implication, where the cycle's numerous political references, allusions, and allegories tapped into a whole tapestry of nation-conscious thought that had been percolating though the German psyche. Syer initially highlights a pair of visions from Sieglinde: a premonition of Siegmund being mauled by Hunding's dogs, and a later nightmare recalling the destruction of her family home. These somnambulistic moments are used as a launching point for Syer to convincingly explore the "varied psychological landscape[s]" (p. 159) of the Ring and their resonances within nation-desiring memory. Hunding's "horn calls" are foregrounded as a musical gesture that alters Sieglinde's consciousness. In particular, their heralding of Hunding's proximity triggers her vision of Siegmund being attacked by dogs, a non-literal prophecy of his impending demise. Syer observes the musical allusions of these motifs to Wagner's earlier work, Der Freischütz, and the Wild Hunt. This segment also gratifyingly pays greater attention to the importance of orchestration than previous analyses. The chapter then redirects its attention to Wotan, surveying the resemblances between the storms that announce his arrivals and the depiction of Artemis/ Diana in Wagner's revision of Iphigénie en Aulide before moving on to the parallels between Wotan and Gluck's Agamemnon, emphasizing the curses their scheming have brought down upon their descendants. Although these sections successfully underline the importance of the German "neo-Hellenistic" movement (p. 161) to the Ring's genesis, ${ }^{9}$ they can get bogged down in excessive plot summary and score analysis of Gluck's operas. In bringing the book to a close, Syer returns to the poetry of Körner and the legacy of the Wild Hunt, concluding that the martyrdom of Siegfried and Brünnhilde represents Wagner's ultimate honouring of Körner's legacy, keeping alive the collective dreams of German liberation associated with his memory.

The ultimate success of Wagner's Visions is how it almost single-handedly creates an original methodology of looking at Wagner's work. Syer notably studies psychology in Wagner without relying on the expected Freudian/Jungian/Lacanian frameworks that have typically characterized psychoanalytic studies of opera. Coupling that originality with a commitment to casting her scholastic eye on topics that are relatively underrepresented in Wagner scholarship (Wagner's early operas, his affinity for Gluck, the influence of Körner), Syer has produced a work that immediately stands out in a heavily populated field. Any and all criticisms I have made above should not be mistaken for reservations about the book's overall significance: Wagner's Visions is a major contribution to Wagner studies, and will hopefully become a valued resource for future scholars.

Daniel Sheridan (McMaster University)

9 Daniel H. Foster, Wagner's Ring Cycle and the Greeks (Cambridge and New York: Cambridge University Press, 2010). 


\section{REFERENCES}

Brandt, Bettina. 2009. "Germania in Armor: The Female Representation of an Endangered German Nation." In Women and Death 2: Warlike Women in the German Literary and Cultural Imagination since 150o, eds. Sarah Colvin and Helen Watanabe-O'Kelly, 86-126. Rochester, NY: Camden House.

Breig, Werner. 1992. “The Musical Works.” In Wagner Handbook. Translated by John Deathridge, eds. Ulrich Müller and Peter Wapnewski, 397-482. Cambridge, MA and London: Harvard University Press.

Crabtree, Alan. 1993. From Mesmer to Freud: Magnetic Sleep and the Roots of Psychological Healing. New Haven, CT. Yale University Press.

Foster, Daniel H. 2010. Wagner's Ring Cycle and the Greeks. Cambridge and New York: Cambridge University Press.

Gibbons, William. "Music of the Future, Music of the Past: Tannhäuser and Alceste at the Paris Opéra," Ninetheenth-Century Music 33, no. 3 (Spring 2010): $232-46$.

Syer, Katherine Rae. 1999. "Altered States: Musical and Psychological Processes in Wagner." PhD diss., University of Victoria.

-2005. "Unseen Voices: Wagner's Musical-Dramatic Shaping of the Grail Scene of Act I." In A Companion to Wagner's Parsifal, eds. William Kinderman and Katherine R. Syer, 177-214. Rochester, NY: Camden House.

Tatar, Maria M. 1978. Spellbound: Studies on Mesmerism and Literature. Princeton, NJ. Princeton University Press.

\section{BIOGRAPHY}

Daniel Sheridan has most recently instructed in music history at McMaster University. He earned a PhD in Cultural Mediations, specializing in Musical Culture, from Carleton University. Daniel has published in such venues as Intersections and The Wagner Journal and is a contributor to The Cambridge Wagner Encyclopedia and The Grove Dictionary of American Music (2nd Edition). He also has forthcoming contributions to the 13th volume of The Bloomsbury Encyclopedia of Popular Music of the World. 